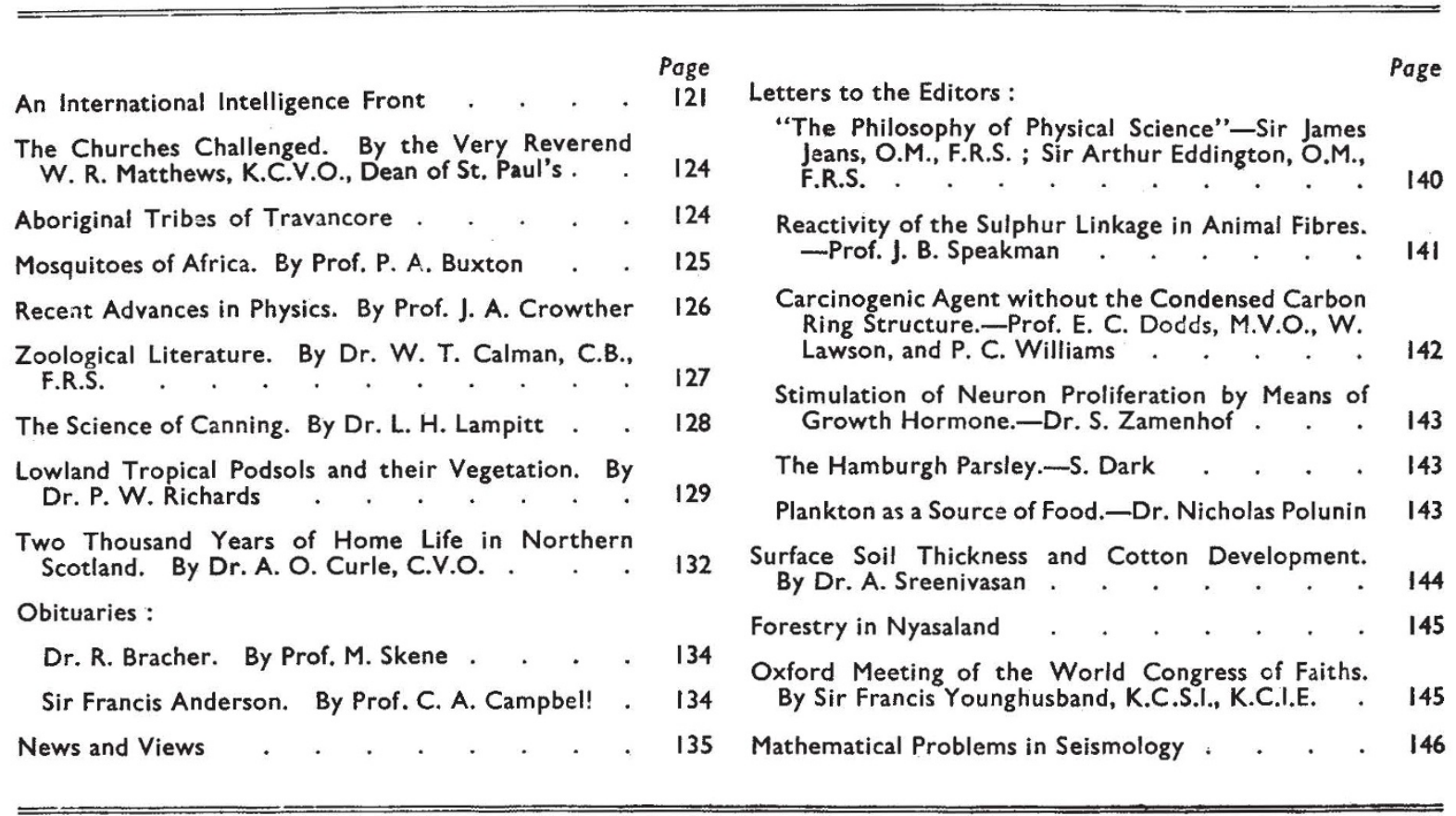

\title{
AN INTERNATIONAL INTELLIGENCE FRONT
}

$\mathrm{F}$ OLLOWING on the establishment last November by the Ministry of Labour of an International Labour Branch as a central agency for making the best possible use of the services and labour of Allied and other friendly foreigners in Great Britain, the industrial registration of friendly aliens which the Ministry commenced on June 9 is a belated step to enlist many valuable heads and hands in our war effort, with the success of which they are as much concerned as ourselves. The man-power position may indeed well make us anxious to secure the very important contribution to our war effort which should be possible from the quarter of a million of these refugees, many of whom could make expert contributions in particular fields.

While, however, the Government has now realized the damage to our national war effort which was done by the policy of internment, which although an urgent necessity at the time of the fall of France has long outlived the emer. gency, there are few signs that either the Government or the nation realizes the moral consequences or the psychological opportunities which were open to us in this field as soon as the migration from Germany under Nazi persecution commenced. These consequences and opportunities have been well portrayed by Sebastian Haffner in a pene- trating survey of the German nation and its leaders and of the possibilities and objectives of Allied propaganda which appeared last year under the title "Germany: Jekyll and Hyde"*. This book is a damning indictment of the policy pursued in the democracies, including the United States, towards such refugees, even before the outbreak of war.

This arresting picture of the deplorable effect of the failure of the democracies to realize before the War the significance of this migration from Germany and, by adopting a generous policy, to establish an anti-Nazi stronghold beyond the reach of the Gestapo is not, however, solely one of opportunities irretrievably lost. It gains fresh interest as the growing stress of the conflict compels us to explore more thoroughly and exhaustively all our moral and material resources. We can no longer, it is true, confront the German Reich with not merely one hundred thousand but a couple of million from among its best, most intelligent and most educated citizens, with all the repercussions on German moral and material reserves which a migration on that scale involves. The Evian conference closed the door on that prospect, which the Nazis were astute enough to fear and to exploit when the danger passed.

* "Germany : Jekyll and Hyde." By Sebastian Haffner. Trans. by Wilfred David. Pp. 320. (London: Secker and Warburg, Ltd., 1940.) 8s. $6 d$. net. 
For all the tragedy of Evian, however, Nazi propaganda is taxed to the utmost to conceal the fact that Germany entered the War as a thoroughly disunited nation and that large sections of her poople fear victory more than defeat. This is still our great psychological opportunity. It can be seized only with the help of the émigrés, and that is the greatest contribution they can offer to our war effort.

It is still possible, however, to use this German anti-Nazi movement both in the fight against Nazism as well as in the subsequent necessary reconstruction of Germany. Far more significant than the formation from them of a German Freedom Legion would be, as Haffner suggests, the formation of a German Academy. The blow to Nazi prestige which such a step could deal is not to be underrated, and might be decisive in winning the War and in preparing the peace. Even more effective might be the utilization of the experience of internal German politics, the knowledge of German political psychology, and the underground ties with Germany which are represented by these émigrés.

Such an organization might well go farther. By supervising the refugees and their military, cultural and political organizations, it would serve as a link with the Allied Governments. It might elaborate plans for Germany's reconstruction and future constitution and establish semi-diplomatic relations with the opposition groups within Germany, through the neutral countries.

If these opportunities are to be seized and such possibilities realized, however, there must be a profound change in the attitude and policy of the Government and indeed of many of the ordinary citizens. The first step in a positive and constructive policy towards Germany is a constructive and positive policy to the German émigré. The great opportunity presented by the offer of cooparation of large numbers of German political intelligentsia, men of science and others, now living outside Germany, and of the many who, mortal foes of the Nazis, are numerous enough to form at least a symbolic kernel of a German army to fight by the side of the Allies, must be grasped. The refugees must not simply be treated with humanity; they must be harnessed to the common cause.

Important as is this political contribution, there is also the question of learning and scholarship represented by these émigrés, among whom is a high proportion of outstanding workers in science, medicine and literature. To this question and its implications Dr. Raymond B. Fosdick, president of the Rockefeller Foundation, once again makes striking reference in his review of the Foundation's work in 1940. Many of the brilliant men with whose work the Foundation was associated are now driven from the posts for which they were trained, debarred from their laboratories, some of them fugitives, some in concentration camps, many of them separated from their families or lost in foreign countries where they sought haven.

The sombre picture of the breakdown in international solidarity, which in the realm of scholarship, at least, had become a vital factor in progress, contained in Dr. Fosdick's review affords a background against which this question of the refugee or émigré must be viewed if we are to keep a true perspective. The conception of knowledge as an international responsibility has vanished from Europe. The free flow of ideas across boundary lines between laboratories and universitics has dried up.

The condition of university life and standards on the Continent, Dr. Fosdick asserts, is now little short of appalling. Due to flight, imprisonment or disappearance, the number of professors in institutions has been reduced by at least $50 \mathrm{pcr}$ cent. Over all the Continental universities hangs the pall of uncertainty and fear. The contact with contemporary life has been abruptly broken. Even when fundamental research is being continued, publication has largely been abandoned $\mathrm{cr}$ postponed. In the social sciences such research as is carried on is confined to innocuous projects which have no relevancy to the present scene. Even neutral countries are under pressure to permit a totalitarian interpretation in teaching such subjects as economics, political science and sociology.

In such surroundings, as Dr. Fosdick reminds us, scholarship withers; nothing short of heroic struggle can keep it alive. It is only free men who dare to think, and it is only through free thought that the soul of a people can be kept alive.

Considerations such as these give pertinence to the suggestion of an émigré academy thrown out by Haffner, particularly if this is not limited to one nationality. The Rockefeller Foundation itself is indeed nobly striving to salvage some proportion of the productive scholarship of the refugees from the conquered countries. Two of its programmes, a placement programme from 1933 to 1939 , and an emergency rescue programme in 1940, have endeavoured to protect the careers of scholars unable to continue work in their native lands. During the seven years ending in 1939, 775,000 dollars were appropriated by the Foundation on the first of these, about 500,000 dollars being allocated to American institutions where 122 individual scholars found places, 99 of whom were established in permanent ${ }^{3}$ positions by the end of 1939 .

In 1940 the second rescue programme was instituted with the assistance of the New School for Social Research and, in the task of permanent 
placement, by the Emergency Committee in Aid of Displaced Foreign Scholars. During 1940, on behalf of the refugee scholars endangered by the invasion of Scandinavia, the Low Countries and France, the Rockefeller Foundation made fifty-six grants totalling 266,350 dollars. The fifty-six scholars assisted included nineteen Germans, eleven French, seven Poles, five Russians, five Austrians, three Norwegians, two Spaniards, one Belgian, one Czech, one Italian and one Swiss. Among them were physiologists, biochemists, mathematicians, neurologists, statisticians, economists, historians, philosophers and philologists. One was a Nobel prize-winner and nearly all had international reputations.

Hopolessly inadequate as efforts of this kind may seem through the restrictions imposed on the occupied territories of Europs, they are not without value. At least they reveal the mockery of science and learning which parades in the raunted New Order of Hitler, and how truly it would sound the death knell of culture and intellectual life. By themselves they are quite inadequate.

To accord to all aliens in sympathy with the ideals for which Britain is fighting the full status of allies with freedom of employment, domicile and movement is only the first step. Utilization of the services of the engineers, chemists, doctors and nurses at present waiting employment would demonstrate the solidarity of an international front against Nazism. The relief it would bring to our war effort is indeed the least of the consequences of such a step-every layman knows well how overburdened are medical men in general practice in almost every part of Great Britain.

What is above all required is a policy towards the émigrés which will enlist as fellow-workers and partners all in sympathy with the ideas and ideals for which we are striving and afford them full opportunity of making their own contribution to that end. That policy must be inspired by a large vision of the psychological possibilities, of the opportunities of a psychological war on Germany which could be carried on with such assistance, thus not merely shortening the war but assisting also to build a stable and better European order after hostilities have ceassed.

To see in the presence of these foreigners, bitterly opposed to the Nazi regime and eager to fight with us to secure its overthrow, not dangers and hindrances to our war effort, real as some of the difficulties which attend an enlightened policy may be, to realize the counterpart to the Allied Governments already present in Great Britain which they represent, demands both courage and imagination. Without these and without magnanimity, such a war as this of ideas and of irreconcilable conceptions, of human values, of justice and of society cannot be won nor an enduring peace achieved. Given, however, the statesmanship alive to the human and moral issues involved, resolute to explore all the possibilities which the position of so many Allied Governments and political leaders from enemy or occupied countries offers tus, and no less keen in its scrutiny of the dangers of treachery or abuse of privilege, decisive action greatly accelerating victory might well be taken. Bold and imaginative steps like the organization of some suitable institution where the great gifts and international reputations of many of these scholars could find ample employ might well set the stream of thought flowing across international frontiers once more, and shatter the pretensions of Hitler and the Nazis to stand even for a united Germany, let alone a wretched regime of slavery and tyranny imposed on one broken country after another. It would, moreover, add to our own effort all the inspiration which comes from a policy conceived in a spirit worthy of the great cause which we are pledged so deeply to defend and the ideals to which the free nations do homage.

\section{THE CHURCHES CHALLENGED}

\section{A Challenge to the Churches}

Religion and Democracy. By John Macmurray. (The Democratic Order, No. 9.) Pp. 63. (London: Kegan Paul and Co., Ltd., 1941.) 1s. net.

$\mathrm{T}$ "HE Churches have had so many "challenges" presented to them that they are becoming accustomed to take them as read, and this indifference is often justified by the ignorance of the challengers, but it is to be hopad that Prof. Macmurray's little book will have serious attention, for it is the cry from the heart of one who knows what Christianity has been and passionately believes in its creative power. In this pamphlet the author is conducting an argument on two fronts; he is pleading with his left-wing associates to realize that without Christianity there cannot be a socialist order which is also free, and he is trying to convince his fellowChristians that the Church needs a new and drastic reformation.

The first of these theses rests upcn an interesting and, as I think, convincing analysis of the tendency 